\title{
THE FINANCIAL STATE OF LOCAL COMMUNITIES: A COMPARATIVE RESEARCH OF UKRAINE AND THE CZECH REPUBLIC
}

\author{
Dmytro KOZLOV 1 , Yuriy DEREV'YANKO ${ }^{\text {, }}$, Vladyslav PIVEN ${ }^{3}$, \\ Leonid MELNYK ${ }^{*}$, Oleksandr KUBATKO ${ }^{5}$ \\ ${ }^{1-5}$ Sumy State University, Sumy, Ukraine \\ "Corresponding author's e-mail: melnyk@econ.sumdu.edu.ua
}

\begin{abstract}
The article describes the specific details of local communities functioning in Ukraine and the Czech Republic. It has been examined that Ukraine and the Czech Republic have similar, but not identical systems of local governance. We conducted a comparative analysis of the financial state of local communities in both countries by five indicators. Indicator 1 (total income per capita) characterises the community's financial potential and reveals that Ukraine's local communities have fewer financial resources to use. Indicator 2 (total expenditures per capita) describes the ability to provide residents with the resources generated in their community and Czech communities have a higher value of this indicator. Indicator 3 (share of the administrative expenditures) shows the effectiveness of money spent, and local communities in both Ukraine and the Czech Republic spend particularly the same part of their total expenditures on administrative needs. Indicator 4 (capital expenditures per capita) demonstrate how the money generated is spent on urgent capital investments and Ukraine's communities have much lower capital expenditures per capita than Czech ones. Indicator 5 (the share of capital expenditures in total expenditures) reflects how local communities perceive the importance of investments in capital projects and Ukraine's communities spend fewer financial resources for capital needs than Czech ones.
\end{abstract}

Keywords: Community, Development, Financial state, Indicator.

JEL Classification: $\mathrm{H} 72$

\section{INTRODUCTION}

The role of local communities all over the world is significant, as their primary goal is to deliver public services effectively and fast (Fourie, et al. 2015). Now when more inclusive governance structures are introduced and civil society organisations are established, local governments become more and more transparent and responsible.

Most central governments regard local communities as important partners in solving a variety of public policy issues and roles, including creating more effective and equitable structures of social services and providing crucial parts of key infrastructure, promoting economic growth and improving living standards.

Decentralizing both the spending and tax authority could improve the resource distribution in the public sector through stronger connections between the costs and 
benefits of local public services (Kolte, 1988, p.2.). The decentralization reform in Ukraine in 2015 turned the position of the unified communities into independent or not so dependent on state governmental political, administrative and financial resources. Nevertheless, the fundamental problem faced by most local governments, in particular small ones, is the widening gap between the availability of financial capital and the spending needs of communities. It is very important in this context to understand whether the communities are effective financially and how to make them more stable and successful.

Many Ukrainian and foreign scientists have researched the role of fiscal decentralization in the socio-economic development of communities, the ways in which they manage local finances, including E. Nelson (Nelson, 2021), B. Neyapti, R. Bahl, T. Williamson, Z. Scott, O. Zizlavsky, T. Baskaran, J.-P. Faguet (Faguet, 2015), O. Pelekhata, etc. Nevertheless, there is a lack of studies concerning the financial state of different local communities and possible obstacles, which do not allow a community to be effective. The comparative study of the development of the communities in both Ukraine and the Czech Republic allows understanding the peculiarities of the communities' functioning and the ways how it can be improved.

\section{METHODS}

Local communities in both Ukraine and the Czech Republic get financial resources with the help of a variety of taxes, including personal income tax, corporate income tax, value-added tax (Cipriani, 2006). Taxes get into local budgets partially, according to the legislative framework. Local finances of the communities also consist of the revenue obtained from local taxes (touristic and ecological ones).

Financial stability of the municipalities in both countries can be evaluated according to five key indicators:

- Total income of a municipality (without transfers) per capita.

- Total expenditures of a municipality per capita.

- Share of the administrative expenditures in the total expenditures of the community.

- Capital expenditures per capita.

- Share of capital expenditures to the total expenditures.

\section{RESULTS}

The goal of the research is to compare the financial state of local communities in Ukraine and the Czech Republic and to investigate the similarities and differences of their economic functioning.

Ukraine and the Czech Republic have similar, but not identical systems of local governance. The Czech Republic has a two-stage, non-hierarchical form of government (Fielding, 1995). Regions were created in 2000 according to Law 129/2000. The Municipal Act 128/2000 regulates the activity of the local communities. Communities, towns ("mesto") and 25 towns ("statutarni mesto") form the structure of local governance. Other cities are given special status under 
the law and may create districts with their own mayor, council and assembly at the sub-municipal level - but only eight cities have selected this option.

The community legislation and the regional legislation, both revised in 2002, differentiate between autonomous duties and delegations (MacDougall, 2003). Local communities are categorised into three groups according to their delegated responsibility: 205 municipalities with extended powers, 1036 municipalities with delegated powers, including 183 municipalities with designated municipal authorities and the rest of which are simple municipalities.

Ukraine has in place a complex three-level sub-national governmental structure, defined by the Constitution. The second level consists of urban and rural districts and regional ("oblast" subordination) villages and the third level consists of small towns and villages, which are step-by-step transforming into the local communities.

In response to Ukraine's high degree of municipal fragmentation, two laws on voluntary municipal amalgamations and on inter-municipal cooperation of territorial communities were adopted successfully in 2015 (Pelekhata, 2013). Two laws on the cooperative municipal merger and inter-communal cooperation of local communities were successfully implemented in 2015 in response to Ukraine's high degree of municipal fragmentation.

As of January 2020, over 4018 local self-regulations have combined since 2015 to form 954 local communities. Likewise, since the Law of Cooperation of Intermunicipal Cooperation has been adopted, the number of agreements increased to more than 80 by July 2017, from 43 in mid-2016 (Petrushenko, 2014). Inter-city co-operation, which also precedes the cycle of amalgamation, primarily includes services such as waste and co-operation in 'second-tier infrastructure', such as the internet, administration, and finance.

Local communities in both Ukraine and the Czech Republic are very similar in the context of financial regulation. Community competences in both countries include education, housing, homes, primary health care, social care services, local roads and public transit, water, and waste management. Under the new system of social change, certain civic competences are being reassigned from local communities to larger municipalities and to the central government. Regional obligations include, however, high-school education, regional highways, public transit, hospitals, and general health care services, community growth and planning, and social assistance to vulnerable groups.

Indicator 1. Total income per capita is calculated as the ratio of general fund revenue flow excluding transfers to the number of municipality's residents (OrtizOspina \& Roser, 2016). That is the total income that is mobilized to the budget of the respective community. This indicator characterises the financial potential of the community, the ability to provide residents with the resources generated in its territory.

Table 1 demonstrates that Ukraine's local communities have higher average total income than the Czech ones. Nevertheless, the Czech communities have much higher total income per capita (766.32 \$) than Ukraine's ones (189.48 \$). The size and the number of communities in both countries explain such a difference between total income and total income per capita (as of 1 January 2020 there were 954 
communities in Ukraine and 6258 ones in the Czech Republic). The maximum total income of a municipality per person in the Czech Republic is higher than the same one in Ukraine. The minimum total income of a municipality (without transfers) per capita in Ukraine is very low (30.4\$), compared to a much higher value (298.6 \$) in the Czech Republic. It is noticeable that the gap in maximum and minimum total income per capita is very significant in Ukraine's communities, and not so huge in the Czech Republic.

Table 1. Indicator 1 (in US dollars)

\begin{tabular}{|c|c|c|c|c|c|}
\hline & $\begin{array}{c}\text { Total income } \\
\text { (avg) }\end{array}$ & $\begin{array}{c}\text { Indicator 1 } \\
\text { (avg) }\end{array}$ & $\begin{array}{c}\text { MAX } \\
\text { (Indicator 1) }\end{array}$ & $\begin{array}{c}\text { MIN } \\
\text { (Indicator 1) }\end{array}$ & $\begin{array}{c}\text { Gap } \\
\text { (MAX/MIN) }\end{array}$ \\
\hline Ukraine & 1935483 & 189.48 & 1429.92 & 30.4 & 47 \\
\hline $\begin{array}{c}\text { The Czech } \\
\text { Republic }\end{array}$ & 1365924 & 766.32 & 2763.97 & 298.6 & 9 \\
\hline
\end{tabular}

Source: Created by the authors, based on the data from (CSO, 2021) and (SSCU, 2021)

Indicator 2. Total expenditures per capita are calculated as the ratio of general fund expenditures to the number of municipality's residents (Wu \& Shi, 2021). This indicator characterises the financial possibilities of the community. Compared to total income per capita (without transfers), Indicator 2 is slightly less objective.

Table 2 demonstrates that Ukraine's local communities have higher average total expenditures than the Czech ones. Nevertheless, Ukraine's communities have much lower total expenditures per capita (274.4 \$) than the Czech ones (1231.74 \$). The maximum total income of a municipality per person in the Czech Republic is more than doubled higher than the same one in Ukraine. The minimum total expenditures of a municipality (without transfers) per capita in Ukraine is very low (30.4 \$), compared to much higher value (298.6 \$) in the Czech Republic. The gap in maximum and minimum total expenditures per capita in Ukraine is 21 times, and in the Czech Republic it is 3 times, which make the whole Czech budgetary system stable.

Table 2. Indicator 2 (in US dollars)

\begin{tabular}{|c|c|c|c|c|c|}
\hline & $\begin{array}{c}\text { Total income } \\
\text { (avg) }\end{array}$ & $\begin{array}{c}\text { Indicator 2 } \\
\text { (avg) }\end{array}$ & $\begin{array}{c}\text { MAX } \\
\text { (Indicator 2) }\end{array}$ & $\begin{array}{c}\text { MIN } \\
\text { (Indicator 2) }\end{array}$ & $\begin{array}{c}\text { Gap } \\
\text { (MAX/MIN) }\end{array}$ \\
\hline Ukraine & 2828156 & 274.4 & 1152.41 & 54.84 & 21 \\
\hline $\begin{array}{c}\text { The Czech } \\
\text { Republic }\end{array}$ & 2106684 & 1231.74 & 2526.42 & 876.97 & 3 \\
\hline
\end{tabular}

Source: Created by the authors, based on the data from (CSO, 2021) and (SSCU, 2021)

Indicator 3. Share of the administrative expenditures (Ivanchuk \& Kharchuk, 2017) to the total expenditures of the community (the ratio of administrative expenditures to the total expenditures). Share of the administrative expenditures demonstrates the effectiveness of money spent. The larger amount of money local communities spend on the administrative needs (for example, salaries of the local deputies or their business trips covering), the less money remains for important capital and non-capital projects. 
Table 3 demonstrates that Ukraine and the Czech Republic spend particularly the same part of their expenditures on administrative needs, which is considered to be an appropriate value even in the business structure. The maximum and minimum share of administrative expenditures are also similar in both countries. The gap (2 times) means that most communities' authorities understand the importance of effective money share.

Table 3. Indicator 3 (in US dollars)

\begin{tabular}{|c|c|c|c|c|}
\hline & $\begin{array}{c}\text { Indicator 3 } \\
\text { (avg) }\end{array}$ & $\begin{array}{c}\text { MAX } \\
\text { (Indicator 3) }\end{array}$ & $\begin{array}{c}\text { MIN } \\
\text { (Indicator 3) }\end{array}$ & $\begin{array}{c}\text { Gap } \\
\text { (MAX/MIN) }\end{array}$ \\
\hline Ukraine & $19.97 \%$ & $29.84 \%$ & $14.97 \%$ & 2 \\
\hline $\begin{array}{c}\text { The Czech } \\
\text { Republic }\end{array}$ & $18.41 \%$ & $27.56 \%$ & $13.86 \%$ & 2 \\
\hline
\end{tabular}

Source: Created by the authors, based on the data from (CSO, 2021) and (SSCU, 2021)

Indicator 4. Capital expenditures per capita (Bojanic, 2013) are defined as the ratio of the capital expenditures of the budget to the number of municipality's residents. The amount of capital expenditures reflects the capacity of the community to provide socio-economic development, opportunities for the implementation of infrastructure development projects, the creation of tangible assets or to obtain the corresponding social effect.

Table 4. Indicator 4 (in US dollars)

\begin{tabular}{|c|c|c|c|c|c|}
\hline & $\begin{array}{c}\text { Total } \\
\text { expenditures } \\
\text { (avg) }\end{array}$ & $\begin{array}{c}\text { Indicator 4 } \\
\text { (avg) }\end{array}$ & $\begin{array}{c}\text { MAX } \\
\text { (Indicator 4) }\end{array}$ & $\begin{array}{c}\text { MIN } \\
\text { (Indicator 4) }\end{array}$ & $\begin{array}{c}\text { Gap } \\
\text { (MAX/MIN) }\end{array}$ \\
\hline Ukraine & 589266 & 61.84 & 847.29 & 9.6 & 88 \\
\hline $\begin{array}{c}\text { The Czech } \\
\text { Republic }\end{array}$ & 616413 & 360.85 & 1241.51 & 169.35 & 7 \\
\hline
\end{tabular}

Source: Created by the authors, based on the data from (CSO, 2021) and (SSCU, 2021)

Table 4 demonstrates that the Czech local communities have higher average total expenditures than Ukraine's ones, though Ukraine's local communities have higher average total expenditures than the Czech ones. It was witnessed that Ukraine's communities spent little money on the capital investments. Ukraine's communities have much lower capital expenditures per capita $(61.84 \$)$ than the Czech ones (360.85 \$). The maximum total capital expenditure per person in the Czech Republic is higher than the same one in Ukraine. The minimum total capital expenditures of a municipality per capita in Ukraine is catastrophically low (9.6\$) compared to a much higher value (169.35\$) in the Czech Republic. The gap in maximum and minimum total expenditures per capita in Ukraine is 88 times, and in the Czech Republic is 7 times. It is crucial for Ukraine's local communities to spend more on capital projects, which are important for the stable socio-economic development of the community.

Indicator 5. The share of capital expenditures to total expenditures is defined as the ratio of capital expenditures to the total expenditures of the community 
(Krivelyova et al., 2013). Though, the value of Indicator 4 depends on the general economic development of the whole country. At the same time, the share of capital expenditures to total expenditures allows realising whether financial resources are used in an effective way.

Table 5 demonstrates that Ukraine's communities spend less part of their expenditures on capital needs than the Czech ones. The maximum and minimum share of administrative expenditures are also similar in both countries. The gap ( 2 times) means that most communities' authorities understand the importance of effective money share in order to provide stable socio-economic development of the community.

Table 5. Indicator 5 (in US dollars)

\begin{tabular}{|c|c|c|c|c|}
\hline & Indicator 5 (avg) & $\begin{array}{c}\text { MAX } \\
\text { (Indicator 5) }\end{array}$ & $\begin{array}{c}\text { MIN } \\
\text { (Indicator 5) }\end{array}$ & Gap (MAX/MIN) \\
\hline Ukraine & $21.05 \%$ & $32.41 \%$ & $18.11 \%$ & 2 \\
\hline The Czech Republic & $29.37 \%$ & $33.89 \%$ & $22.48 \%$ & 2 \\
\hline
\end{tabular}

Source: Created by the authors, based on the data from (SCO, 2021) and (SSCU, 2021)

\section{CONCLUSION}

The comparative analysis of the financial state of local communities in Ukraine and the Czech Republic has been conducted. The theoretical part of the study describes the specific details of functioning of local communities in both countries. It has been examined that Ukraine and the Czech Republic have similar, but not identical systems of local governance.

Indicator 1 (total income per capita), which characterises the financial potential of the community, reveals that Ukraine's local communities have less financial resources to use, which has a direct impact on the economic situation in the community.

Indicator 2 (total expenditures per capita) describes the ability to provide residents with the resources generated in the community. Czech communities have a higher value of this indicator, which means that they spend more financial resources (five times more than Ukraine's ones). The large gap between the maximum and minimum value of Indicators 1 and 2 shows significant differentiation in financial possibilities of various local communities within one country.

Indicator 3 (share of the administrative expenditures to the total expenditures of the community) shows the effectiveness of money spent. It is revealed that local communities in both Ukraine and the Czech Republic spend particularly the same part of their total expenditures on the administrative needs. It seems to be positive that these values do not exceed $20 \%$ in average, because it allows local communities to spend more on important projects.

Indicator 4 (capital expenditures per capita) demonstrates how money generated is spent on urgent capital investments, which are very important for balanced socio-economic and financial development. Ukraine's communities have 
much lower capital expenditures per capita than the Czech ones, which provide them with fewer opportunities for crucial future development.

Indicator 5 (the share of capital expenditures to total expenditures), which is not particularly dependable on the general level of economic development, reflects how local communities perceive the importance of investments in capital projects. It demonstrates that Ukraine's communities spend fewer financial resources on capital needs than the Czech ones.

\section{REFERENCES}

Bojanic, A. N. (2013). The composition of government expenditures and economic growth in Bolivia. Latin American Journal of Economics, 50(1), 83-105. https://doi.org/10.7764/laje.50.1.83

Czech Statistical Office, CSO (2021). Public Database of the Czech Republic. Retrieved from https://vdb.czso.cz/vdbvo2/faces/en/index.jsf?page=home. Actual at 12.08.2021.

Cipriani, G. (2006). The responsibility for implementing the Community budget. CEPS Working Documents. No. 247, CEPS, Brussels. Retrieved from https://www.files.ethz.ch/isn/25342/247 Implemeting\%20Community\%20Budget.pdf

Faguet, J-P \& Pöschl, C. (2015). Is decentralization good for development? Perspectives from academics and policy makers. In Faguet, Jean-Paul and Pöschl, Caroline, (eds.) Is Decentralization Good for Development? Perspectives from Academics and Policy Makers. Oxford University Press, Oxford, pp. 1-29. Retrieved from http://eprints.lse.ac.uk/63178/

Fielding, N. G. (1995). Community policing. Oxford: Clarendon Press. https://doi.org/10.1093/acprof:oso/9780198260271.001.0001

Fourie, M. L., Opperman, L., Scott, D., \& Kumar, K. (2015). Municipal finance and accounting. Van Schaik Publishers.

Ivanchuk, N., \& Kharchuk, Y. (2017). Administrative Expenditures of Social Security Funds in Ukraine. Baltic Journal of Economic Studies, 3(5), 157-161. https://doi.org/10.30525/2256$\underline{0742 / 2017-3-5-157-161}$

Kolte, L. (1988). Community Budget: New Principles for Finance, Expenditure Planning and Budget Discipline. The Common Market L. Rev., 25, 487-501.

Krivelyova, A., Kakietek, J., Connolly, H., Bonnel, R., Manteuffel, B., Rodriguez-García, R., N'Jie, N. D., Berruti, A., Gregson, S., \& Agrawal, R. (2013). Funding and expenditure of a sample of community-based organizations in Kenya, Nigeria, and Zimbabwe. AIDS Care, 25(sup1). https://doi.org/10.1080/09540121.2013.764390

MacDougall, D. (2003). Economic and monetary union and the European Community budget. In Mark Baimbridge \& Philip Whyman (ed.), Economic and Monetary Union in Europe, chapter 7, Edward Elgar Publishing. https://doi.org/10.4337/9781781009697

Nelson, J. A. (2021). Economics and community knowledge-making, Journal of Economic Methodology, 28(1), 107-113, https://doi.org/10.1080/1350178X.2020.1868778

Ortiz-Ospina, E. \& Roser, M. (2016). Government Spending. Published online at OurWorldInData.org. Retrieved from https://ourworldindata.org/government-spending

Pelekhata, O. V. (2013). Capital budget as instrument of maintenance infrastructure of consolidated rural communities. Socio-economic problems of the modern period of Ukraine, 6(104), 355-361. Retrieved from http://nbuv.gov.ua/UJRN/sepspu_2013_6 40 [In Ukrainian].

Petrushenko, Y. (2014). Analysis of the Stability of Local Budgets in the Context of Financial Policy of the Territorial Communities Development. European Journal of Economic Studies, 3, 170176. [in Ukrainian].

State Statistics Service of Ukraine, SSCU (2021). Statistical data from http://www.ukrstat.gov.ua/ [In Ukrainian]. Actual at 12.08.2021.

Wu, Y. \& Shi, Y. (2021). Does General Fund Balance Stabilize Municipal Expenditure? Evidence from Large American Cities. International Journal of Public Administration, 44(5), 420-429, https://doi.org/10.1080/01900692.2020.1728772 


\section{AUTHORS' SHORT BIOGRAPHIES}
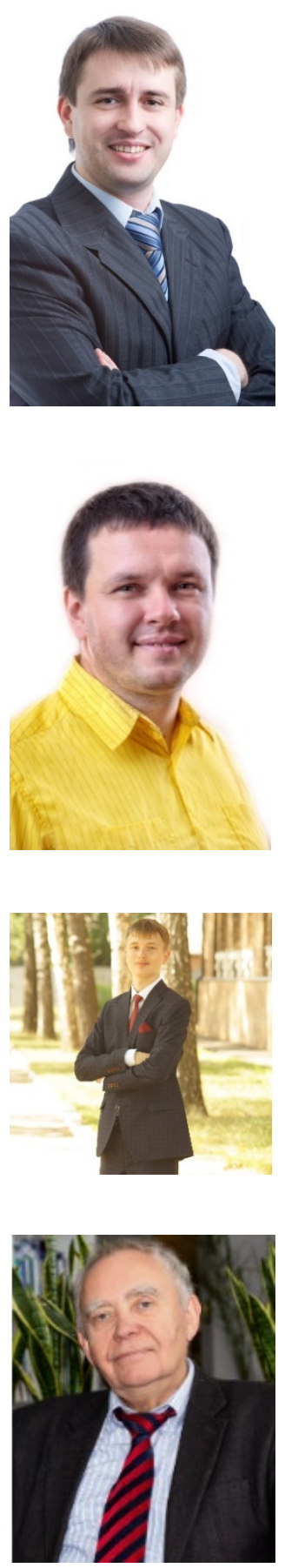

Leonid Hr. Melnyk - Doctor of Economics, Professor of the Department of Economics, Entrepreneurship and Business Administration, Sumy State University (Sumy, Ukraine); Chairman of Sumy Branch of Academy for Business and Management of Ukraine.

Educational background: He received a Doctoral degree in Economics from Moscow Institute of National Economy in 1989. He received a Candidate degree in Economics from Moscow Institute of Steel and Alloys in 1978. He received an Honours Degree of Mechanical Engineer from Kharkiv Polytechnic Institute in 1971. Areas of professional research: development economics, ecological economics, economics and business, the third industrial revolution and industry 4.0, economics of systems development, information economics, social and economic EU studies, economics of sustainability.

E-mail: melnyk@econ.sumdu.edu.ua

ORCID iD: https://orcid.org/0000-0001-7824-0678 


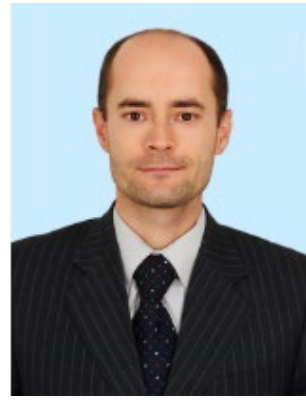

Oleksandr V. Kubatko, Doctor of Economics, Professor of the Department of Economics, Entrepreneurship and Business Administration, Sumy State University (Sumy, Ukraine); Deputy Head of Economics and Business Administration Department for International Activities, Vice-Chief Editor of the international journal "Mechanism of Economic Regulation". Educational background: He received an MA degree in Economic Theory from Kyiv-Mohyla Academy in 2008. In 2010, he received the Candidate of Economic Sciences degree in the specialty 08.00.06 "Economics of Nature Management and Environmental Protection". In 2018, he received the degree of Doctor of Economics.

E-mail: okubatko@econ.sumdu.edu.ua

ORCID iD: https://orcid.org/0000-0001-6396-5772 